Unnes Journal of Public Health

\title{
KAJIAN STRATEGI PROMOSI KESEHATAN SANITASI TOTAL BERBASIS MASYARAKAT (STBM) KELURAHAN TIRTO KECAMATAN PEKALONGAN BARAT KOTA PEKALONGAN
}

\author{
Yulis Indriyani $^{\circledR}$, Yuniarti, dan Rr. Vita Nur Latif \\ Prodi Kesehatan Masyarakat, Fakultas Ilmu Kesehatan, Universitas Pekalongan, Indonesia
}

\section{Info Artikel}

Sejarah Artikel:

Diterima 30 Juni 2016

Disetujui 5 Juli 2016

Dipublikasikan Juli 2016

Keywords:

CBTS; Community

Empowering; Strategy

Abstrak

Sanitasi Total Berbasis Masyarakat (STBM) merupakan pendekatan untuk mengubah perilaku menjadi higienis dan saniter melalui pemberdayaan masyarakat dengan cara pemicuan. Fenomena yang terjadi di Kelurahan Tirto masih terdapat perilaku BABS sebanyak $84 \mathrm{KK}$, perilaku buang sampah secara sembarangan, dan mengalirkan limbah cair rumah tangga ke sungai. Penelitian ini mengkaji secara mendalam strategi promosi kesehatan STBM di Kelurahan Tirto. Metode yang digunakan adalah studi kasus dengan desain eksploratoris kualitatif. Pencapaian lima pilar STBM di Kelurahan Tirto belum maksimal yaitu pada pilar stop BABS dan pilar pengelolaan limbah cair rumah tangga secara aman. Hambatan yang mempengaruhi diantaranya belum diterapkan tindakan tegas bagi pelaku pembuangan feses ke sungai, belum adanya pelatihan teknis STBM bagi tokoh masyarakat, metode CLTS bersifat terbatas di satu $R W$, dan masyarakat Kelurahan Tirto belum mengoptimalkan swadaya untuk menambah septic tank dan bak penampungan air limbah.
\end{abstract}

\begin{abstract}
Community-based total sanitation (CBTS) is an approaching method to mobilise community to improve hygiene and sanitation through triggering collective behaviour change. Tirto Village had 84 households wich still practice open defecation, littering and disposing wastewater into river. This research aimed to study the health promotion strategy of CBTS in Tirto Village, Pekalongan City. It was a case study with qualitative exploratory design. Tirto Village had not reached the five pillars optomally yet. The two pillars which were not optimally reached by Tirto Village were pillar of free open defecation and pillar of proper wastewater treatment. The influenced factors were there was no punishment for open defecation doer, there was no CBTS technical training for community figures yet, CLTS methode was applied to only one community unit and there was no initiation yet from the community to add septic tanks and wastewater disposal facilities.
\end{abstract}

(C) 2016 Universitas Negeri Semarang

\footnotetext{
Alamat korespondensi:

Prodi Kesehatan Masyarakat, Fakultas Ilmu Kesehatan

Universitas Pekalongan, Gedung D Lantai 1, JL. Sriwijaya No.3

Pekalongan

E-mail: indriyaniyulis@yahoo.com
} 


\section{PENDAHULUAN}

Sanitasi termasuk kajian penting karena merupakan salah satu aspek mendasar sebagai hak asasi manusia dari masyarakat dan memiliki dampak yang luas ketika pembangunan sanitasi terabaikan. Pencapaian sanitasi di negara kita yang belum tuntas menjadi tantangan besar pada era pasca Millenium Development Goals (MDGs). Terlebih target 100\% pencapaian akses universal sanitasi di tahun 2019 mendatang. Strategi secara komprehensif dalam implementasi solusi alternatif permasalahan tersebut sangatlah berarti.

Berdasarkan Bappenas (2015) akses sanitasi layak mencapai $62 \%$. Data profil kesehatan (2014) menunjukkan bahwa akses sanitasi layak (jamban sehat) di Jawa Tengah mencapai $63,2 \%$. Ada kesenjangan untuk memenuhi target akses universal sanitasi di tahun 2019, sehingga dibutuhkan kerja keras untuk mencapai angka 100\%.

Data yang bersumber dari Dinas Kesehatan Kota Pekalongan (2014) menunjukkan bahwa seluruh kelurahan di Kota Pekalongan sudah melaksanakan STBM, namun kelurahan yang berhasil mencapai indikator pilar pertama yaitu kelurahan dengan status Stop Buang Air Besar Sembarangan (SBS)/ Open Defecation Free (ODF) berjumlah 10 kelurahan dari 47 kelurahan di Kota Pekalongan atau 21,27\%.

Hasil laporan Puskesmas Tirto tahun 2014 menunjukkan bahwa, jumlah penduduk Kelurahan Tirto 10.798, jumlah $\mathrm{RW}=8$, RW yang $O D F$ ada 6 , jumlah Kepala Keluarga $(\mathrm{KK})=2687$, jumlah rumah $=2134$, jumlah jamban 2050, KK yang sudah $O D F=2603, \mathrm{KK}$ yang masih Buang Air Besar Sembarangan (BABS) = 84. Hal tersebut belum sesui dengan target.

Hasil observasi di Kelurahan Tirto menunjukkan bahwa masyarakat masih membudayakan perilaku buang sampah secara sembarangan seperti buang sampah di sungai, selokan, dan tempat terbuka (lahan rumah). Pengelolaan limbah cair rumah tangga di wilayah Tirto belum tepat karena masyarakat pada umumnya mengalirkan limbah cair rumah tangga (limbah deterjen dan air bekas mandi/cuci pakaian) ke selokan maupun secara langsung menuju sungai. Pembuangan yang tidak aman tersebut dapat menimbulkan penyakit akibat sanitasi yang buruk.

Berdasarkan fenomena di atas, maka peneliti bermaksud mengkaji secara mendalam strategi promosi kesehatan Sanitasi Total Berbasis Masyarakat di Kelurahan Tirto Kecamatan Pekalongan Barat Kota Pekalongan. Secara lebih khusus tujuan penelitian ini antara lain adalah:

a. Mengkaji secara mendalam advokasi meliputi kebijakan, komitmen, dana, disposisi publik, dan sarana prasarana Sanitasi Total Berbasis Masyarakat di Kelurahan Tirto Kecamatan Pekalongan Barat Kota Pekalongan.

b. Mengkaji secara mendalam bina suasana meliputi koordinasi, sosialisasi program, dan pelatihan Sanitasi Total Berbasis Masyarakat di Kelurahan Tirto Kecamatan Pekalongan Barat Kota Pekalongan.

c. Mengkaji secara mendalam pemberdayaan masyarakat meliputi pemicuan Sanitasi Total Berbasis Masyarakat di Kelurahan Tirto Kecamatan Pekalongan Barat Kota Pekalongan.

d. Menyusun strategi baru pada strategi promosi kesehatan Sanitasi Total Berbasis Masyarakat di Kelurahan 
Tirto Kecamatan Pekalongan Barat Kota Pekalongan.

\section{METODE PENELITIAN}

Lokasi penelitian ini adalah Kelurahan Tirto Kecamatan Pekalongan Barat Kota Pekalongan. Penelitian ini telah dilakukan pada bulan Desember 2015 hingga Mei 2016. Output penelitian ini adalah strategi baru pada strategi promosi kesehatan STBM di Kelurahan Tirto. Penelitian ini difokuskan pada pendekatan strategi promosi kesehatan. Pendekatan tersebut meliputi beberapa variabel advokasi, bina suasana, dan pemberdayaan masyarakat. Peneliti mengklasifikasikan masing-masing variabel di atas dengan modifikasi teori implementasi menurut Anderson (1979) yaitu keterlibatan, kepatuhan, administratif, dan dampak. Variabel advokasi meliputi kebijakan, komitmen, dana, disposisi publik, dan sarana prasarana. Variabel bina suasana meliputi koordinasi, sosialisasi program, dan pelatihan. Variabel pemberdayaan masyarakat meliputi pemicuan. Sehingga variabel yang akan diteliti berjumlah sembilan variabel.

Jenis penelitian yang digunakan dalam penelitian ini menggunakan desain eksploratoris kualitatif. Penelitian eksploratoris yaitu penelitian yang berusaha menggali atau mengeksplor lebih dalam elemen/variabel yang diteliti. Rancangan penelitian ini menggunakan metode studi kasus. Riset dengan metode studi kasus menghendaki suatu kajian yang rinci, mendalam, menyeluruh atas objek tertentu (Susila, dkk, 2013:229).

Informan penelitian ini terdiri dari Informan Utama (Pelaksana BKM, Seksi Kesmas \& Tokoh Masyarakat, Natural Leader, dan Kader STBM) dan Informan Triangulasi (Warga Kelurahan Tirto dan Sanitarian Puskesmas Tirto). Metode pengumpulan data penelitin ini meliputi data primer dan data sekunder. Data primer diperoleh dari wawancara mendalam dan observasi. Data sekunder diperoleh dari dokumentasi dan studi kepustakaan. Adapun alat pengumpulan data berupa pedoman wawancara, alat perekam, dan catatan lapangan.

\section{HASIL DAN PEMBAHASAN}

\section{Profil Kelurahan Tirto}

Kelurahan Tirto merupakan wilayah yang terletak di Kecamatan Pekalongan Barat Kota Pekalongan. Luas wilayah Kelurahan Tirto 141,7 Km. Berdasarkan orbitasi potensi sumber daya alam, Kelurahan Tirto termasuk wilayah yang rawan terjadi banjir. Kelurahan Tirto terdiri dari 3 dukuh yaitu meduri, tirto, dan peturen. Kelurahan Tirto terdiri dari $8 \mathrm{RW}$ dan 40 RT. Berdasarkan profil Kelurahan Tirto tahun 2014, Kelurahan Tirto memiliki penduduk sebanyak 10.455 jiwa.

Tabel 1. Distribusi Penduduk dengan Akses terhadap Fasilitas Sanitasi Layak (Jamban Sehat) di Kelurahan Tirto

\begin{tabular}{|lll|}
\hline No & Jenis Jamban & Jumlah \\
\hline 1 & Komunal & 12 \\
\hline 2 & Leher Angsa & 1420 \\
\hline 3 & Plengsengan & 0 \\
\hline 4 & Cemplung & 0 \\
\hline
\end{tabular}




\begin{tabular}{|l|}
\hline Total 1432 \\
\hline
\end{tabular}

Sumber: Profil Puskesmas Tirto (2014)

Berdasarkan tabel 1 dapat diketahui jamban leher angsa sebanyak 1420 unit, bahwa distribusi penduduk dengan akses jenis jamban plengsengan sebanyak 0 unit, terhadap fasilitas sanitasi layak (jamban dan jenis jamban cemplung sebanyak 0 sehat) di Kelurahan Tirto yaitu jenis jamban unit.

komunal sebanyak 12 unit, jenis

Tabel 2. Distribusi Tempat Pengelolaan Makan (TPM) Menurut Status Higiene Sanitasi di Kelurahan Tirto

\begin{tabular}{|lll|}
\hline No & Tempat Pengelolaan Makan & Jumlah \\
\hline 1 & Jasa Boga & 1 \\
\hline 2 & Rumah Makan/ Restoran & 1 \\
\hline 3 & Depot Air Minum & 4 \\
\hline 4 & Makanan Jajanan & 20 \\
\hline Total & & 26 \\
\hline
\end{tabular}

Sumber: Profil Puskesmas Tirto (2014)

Berdasarkan tabel 2 dapat diketahui bahwa distribusi tempat pengelolaan makan menurut status higiene sanitasi di Kelurahan tirto yaitu tempat pengelolaan makan jasa boga sebanyak 1 unit, rumah makan/ restoran sebanyak 1 unit, depot air minum sebanyak 4 unit, dan makanan jajanan sebanyak 20 unit.

Tabel 3. Prasarana Air Bersih

\begin{tabular}{|lll|}
\hline No & Prasarana Air Bersih & Jumlah \\
\hline 1 & Sumur & - \\
\hline 2 & Sumur gali & 245 \\
\hline 3 & Hidran umum & 8 \\
\hline 4 & MCK & 5 \\
\hline Total & & 258 \\
\hline
\end{tabular}

Sumber: Profil Kelurahan Tirto (2014)

Berdasarkan tabel 3 dapat diketahui bahwa prasarana air bersih di Kelurahan Tirto yaitu sumur sebanyak 0 unit, sumur gali sebanyak 245 unit, hidran umum sebanyak 8 unit, dan MCK sebanyak 5 unit.

\section{Strategi Promosi Kesehatan STBM}

Secara general penerapan strategi promosi kesehatan pada lima pilar STBM di Kelurahan Tirto dapat dijelaskan sebagai berikut:

a. Advokasi STBM (kebijakan, komitmen, dana, disposisi publik, dan sarana prasarana) di Kelurahan Tirto diantaranya melalui upaya dukungan kebijakan baik tertulis maupun non tertulis. Secara tertulis, pihak kelurahan memprioritaskan sanitasi dalam dokumen perencanaan. Selain itu, kader 
berupaya membina masyarakat untuk mewujudkan kelurahan $O D F$. Hal tersebut senada dengan komitmen yang diupayakan oleh Kelurahan Tirto yaitu diwujudkan dalam bentuk tertulis dan non tertulis atau tindakan seperti penyuluhan CLTS (Community-Led Total Sanitation). Adapun dana untuk menyelenggarakan STBM berasal dari BOK (Bantuan Operasional Kesehatan) serta swadaya dari masyarakat Kelurahan Tirto. Respon masyarakat terhadap STBM sudah baik. Pada mulanya masyarakat memiliki budaya $\mathrm{BAB}$ di sungai, kemudian dilakukan berbagai upaya kesehatan seperti pemicuan STBM sehingga masyarakat tahu akan dampak BAB sembarangan. Hal tersebut memicu masyarakat untuk mau melakukan perubahan perilaku

stop BABS melalui upaya pendampingan. Akhirnya sebagian masyarakat Tirto mampu melakukan praktik stop BABS meskipun belum mencapai target $100 \%$. Sarana prasarana pilar 1 STBM yang sudah terwujud di Kelurahan Tirto yaitu WC USRI dan jamban komunal. Selain itu, tempat cuci tangan pakai sabun, TPS (Tempat Pembuangan Sampah) $3 \mathrm{R}$, dan SPAL (Saluran Pembuangan Air Limbah).

b. Bina Suasana STBM (koordinasi, sosialisasi program, dan pelatihan) di Kelurahan Tirto diantaranya melalui koordinasi dengan berbagai pihak seperti puskesmas, kelurahan sendiri, BAPPEDA, kerjasama dengan tokoh masyarakat, tokoh agama, dan kader. Sosialisasi STBM di Kelurahan Tirto melibatkan tokoh masyarakat. Adapun pelatihan STBM baik secara administrasi maupun teknis pernah dilakukan di Kelurahan Tirto. Sasaran pelatihan tersebut adalah satuan pelaksana PAMSIMAS. Narasumber berasal dari fasilitator STBM pusat, Dinas Kesehatan, dan BAPPERMAS.

c. Pemberdayaan Masyarakat STBM di Kelurahan Tirto diantaranya melalui metode pemicuan. Metode tersebut digunakan untuk menyadarkan masyarakat merubah perilaku $\mathrm{BAB}$ sembarangan.Pemicuanyang dilakukan dengan mencontohkan segelas air minum kemudian diberi rambut yang terkontaminasi dengan feses. Cara ini merangsang jijik masyarakat untuk stop BAB sembarangan. Kondisi pilar 1 STBM tentang stop buang air besar di Kelurahan Tirto belum 100\% ODF karena masih ada warga yang $\mathrm{BAB}$ sembarangan.Pascapemicuan dilakukan survei rumah untuk memantau perkembangan perubahan perilaku BAB sembarangan. Selain hal tersebut, masyarakat di Kelurahan Tirto sudah secara mandiri melaksanakan perilaku cuci tangan pakai sabun, mengelola makanan dan minuman secara aman, dan mengelola sampah secara aman. Namun, pembuangan limbah cair khususnya rumah tangga belum maksimal dikarenakan masih banyak masyarakat sekitar membuang limbah tersebut ke sungai.

\section{Karakteristik Informan}

Informan penelitian ini terdiri dari informan utama dan informan triangulasi yaitu sebagai berikut:

Tabel 4. Karakteristik Informan Utama 
Indriyani, Yuniarti, \& Latif / Unnes Journal of Public Health 5 (3) (2016)

\begin{tabular}{|c|c|c|c|c|}
\hline No & Jenis Informan & $\begin{array}{l}\text { Jenis } \\
\text { Kelamin }\end{array}$ & Alamat & Pekerjaan \\
\hline 1 & Informan utama 1 & Laki-laki & $\begin{array}{lll}\text { J1. } & \text { KH. } & \text { Ahmad } \\
\text { Dahlan Gg.7 No.18 }\end{array}$ & $\begin{array}{l}\text { Pelaksana BKM } \\
\text { Kelurahan Tirto }\end{array}$ \\
\hline 2 & Informan utama 2 & Perempuan & Kelurahan Tirto & $\begin{array}{l}\text { Seksi Kesmas } \\
\text { Kelurahan Tirto }\end{array}$ \\
\hline 3 & Informan utama 3 & Laki-laki & $\begin{array}{l}\text { Kelurahan } \\
04 / 04\end{array}$ & Pengusaha \\
\hline 4 & Informan utama 4 & Laki-laki & $\begin{array}{ll}\text { Kelurahan } & \text { Tirto } \\
03 / 02 & \end{array}$ & $\begin{array}{l}\text { Anggota LPM } \\
\text { Kelurahan Tirto }\end{array}$ \\
\hline 5 & Informan utama 5 & Perempuan & $\begin{array}{l}\text { Kelurahan } \\
06 / 03\end{array}$ & Pedagang \\
\hline
\end{tabular}

Tabel 5. Karakteristik Informan Triangulasi

\begin{tabular}{|lllll|}
\hline No & Jenis Informan & Jenis & Alamat & Pekerjaan \\
& & Kelamin & & \\
\hline 1 & Informan triangulasi 1 & Laki-laki & Pringlangu 04/03 & Sanitarian \\
& & & & $\begin{array}{l}\text { Puskesmas } \\
\text { Tirto }\end{array}$ \\
& & & & Warga \\
\hline 2 & Informan triangulasi 2 & Perempuan & KelurahanTirto & $03 / 02$ \\
& & & & \\
\hline
\end{tabular}

\section{Analisis SWOT}

Peneliti menggunakan analisis SWOT berdasarkan temuan di lapangan atau hasil penelitian tentang strategi promosi kesehatan pada lima STBM di Kelurahan Tirto. Analisis SWOT tersebut melalui beberapa tahapan-tahapan yaitu Analisis Lingkungan Stratejik (Internal \&
Eksternal), Kesimpulan Analisis Faktor Internal (KAFI) dan Kesimpulan Analisis Faktor Eksternal (KAFE), Analisis SWOT, Penentuan Urutan Asumsi Stratejik Pilihan (ASAP), Faktor Kunci Keberhasilan (FKK), dan Penyusunan Tujuan, Sasaran, dan Strategi

Tabel 6. Matrik Analisis Lingkungan Stratejik (Internal \& Eksternal)

\begin{tabular}{|lll|}
\hline Internal & Eksternal \\
\hline Kekuatan & Peluang \\
Adanya upaya dukungan kebijakan dan & Fasilitator STBM yaitu sanitarian \\
komitmen yang baik dari Kelurahan Tirto. & Puskesmas Tirto pro-aktif dalam \\
DanaSTBMberasaldariswadaya & kegiatan STBM. & \\
masyarakat. & Adanya Bantuan Operasional \\
Sarana prasarana WC USRI, jamban & Kesehatan (BOK) pusat untuk \\
komunal, tempat cuci tangan, TPS 3 R, dan & mendukung STBM. \\
SPAL sudah tersedia di Kelurahan Tirto. & Koordinasi lintas sektor terkait lima \\
Respon masyarakat yang antusias. & pilar STBM. \\
\hline Kelemahan & Ancaman \\
\hline Lambannya perubahan perilaku stop buang & \multicolumn{2}{c|}{ Output dari program PAMSIMAS } \\
air besar sembarangan masyarakat Kelurahan & kecenderungan berupa bantuan fisik \\
Tirto. & \multicolumn{2}{c}{ dapat memanjakan masyarakat di } \\
\hline
\end{tabular}


Model CLTS walaupun kelompok tetapi Kelurahan Tirto.

terbatas satu RW saja. Kelurahan Tirto menjadi muara

Belum maksimalnya bak penampungan pembuangan limbah cair rumah

limbah cair rumah tangga di Kelurahan Tirto. tangga dari Kabupaten Pekalongan

Tokoh masyarakat belum mendapatkan menuju ke Kota Pekalongan.

pelatihan STBM.

Paradigma masyarakat Kelurahan Tirto yang

menuntut bantuan fisik untuk sanitasi.

\section{Stop Buang Air Besar Sembarangan}

Stop BAB secara sembarangan atau

ODF (Open Defecation Free) merupakan pilar

1 STBM. Saat ini capaian $O D F$ di

Kelurahan Tirto belum maksimal. Ada

peningkatan perubahan perilaku

masyarakat untuk Stop BAB secara

sembarangan di Kelurahan Tirto, namun

belum $100 \% \quad O D F$. Perubahan yang

demikian dapat dikatakan lamban. Upaya

bantuan fisik berupa jamban dari pemerintah kepada masyarakat tidak cukup untuk meningkatkan capaian $O D F$. Selain itu, pelatihan yang telah diselenggarakan baik secara administratif maupun teknis pun belum dapat berkontribusi pada pencapaian $O D F$ secara signifikan. Penerapan model CLTS oleh fasilitator STBM dari Puskesmas Tirto untuk pilar 1 STBM juga belum dapat menerobos angka $0 \%$ Stop BAB sembarangan.

Terdapat hambatan-hambatan terhadap permasalahan di Kelurahan Tirto yang masih menitikberatkan pada pencapaian pilar $O D F$. Dilihat dari strategi advokasi yang telah dilakukan Kelurahan Tirto terdapat poin yang belum maksimal yaitu komitmen yang konsisten sebagaimana hasil riset terdahulu oleh Sidjabat (2012). Konsistensi komitmen $O D F$ Kelurahan Tirto dapat dipertegas dengan kebijakan yang dituangkan melalui penetapan punisment pada perilaku masyarakat buang air besar sembarangan. Hal itu dapat menjadi peluang tercapainya kelurahan $O D F$. Punisment ini dapat dilakukan melalui cara denda/ membayar atas tindakan membuang feses ke sungai sebagai upaya peringatan tegas untuk merubah perilaku tersebut. Hasil denda tersebut yang terkumpul nantinya dapat digunakan untuk membantu masyarakat yang tidak mempunyai sarana septic tank. Sehingga secara mandiri masyarakat Kelurahan Tirto dapat menyediakan akses pembuangan feses berupa septic tank dan tidak membuang feses ke sungai. Hal tersebut dapat menjadi peluang besar untuk pencapaiaan kelurahan $O D F$ jika dilakukan secara maksimal.

Sesuai sudut pandang sasaran program STBM pilar 1 (masyarakat), selain strategi-strategi diatas yang belum maksimal kesadaran masyarakat yang rendah (masyarakat yang mengalirkan pembuangan feses ke sungai karena tidak memiliki septic tank) menjadi faktor pencetus terhambatnya capaian status $O D F$. Mereka belum sepenuhnya memahami dampak ataupun resiko yang akan tampak, sungai yang terkontaminasi feses dapat menularkan berbagai penyakit berbasis lingkungan (diare) serta menjadi tempat berkembang biaknya (habitat) virus atau bakteri (Wandansari, 2014). Sehingga, perlu upaya untuk dapat menyentuh nurani masyarakat. Hal ini erat kaintannya dengan peran tokoh masyarakat yang telah

diberikan pelatihan STBM untuk mendampingi mereka dalam upaya menuju 
stop BABS (Yimam, et al., 2014). Jika kesadaran masyarakat Kelurahan Tirto tinggi, maka bisa mendongkrak komitmen untuk mencapai kelurahan $O D F$. Rasa berkebutuhan yang sama akan membentuk komitmen bersama yang kuat untuk meningkatkan sanitasi komunitas (Windraswara, 2009).

\section{Cuci Tangan Pakai Sabun}

Cuci tangan pakai sabun merupakan pilar 2 STBM. Praktek mencuci tangan sangat penting untuk menghindarkan individu dari infeksi. Hal tersebut dibuktikan dalam penelitian Trikora dan Siwiendrayanti (2015) dimana praktek mencuci tangan berhubungan dengan kejadian diare. Penelitian Peltzer dan Pengpid (2014) juga menunjukkan bahwa kebersihan tangan menjadi faktor pencegah berbagai risiko kesehatan pada siswa remaja di empat negara ASEAN. Pencapaian budaya cuci tangan pakai sabun di Kelurahan Tirto sulit untuk diukur

karena praktiknya berada didalam kehidupan sehari-hari masyarakat. Namun, sudah ada komitmen masyarakat untuk andil dalam membudayakan perilaku CTPS ini. Fasilitator STBM telah membantu untuk mendukung pilar tersebut melalui penyelenggaraan pengadaan sarana tempat cuci tangan di sekolah-sekolah wilayah Kelurahan Tirto. Pengadaan sarana seperti tempat cuci tangan merupakan fasilitasi pengembangan penyelenggaraan STBM oleh pemerintah daerah sebagaimana dikutip dalam Peraturan Menteri Kesehatan (2014). Sosialisasi langkah-langkah CTPS sering dilaksanakan pada pertemuanpertemuan seperti pertemuan pihak sekolah dengan wali murid, PKK, posyandu, maupun pertemuan FKSS. Selain itu, praktik bersama CTPS sering dilakukan di tingkat sekolah baik PAUD maupun sekolah dasar.

\section{Pengelolaan Makanan dan Minuman Rumah} Tangga

Pengelolaan makanan dan minuman rumah tangga secara aman merupakan pilar 3 STBM. Capaian pilar 3 STBM di Kelurahan Tirto cukup baik. Indikatornya antara lain masyarakat membudayakan perilaku mencuci bahan makanan sebelum dimasak atau diolah, menggunakan air bersih untuk keperluan minum sehari-hari serta merebusnya, membudayakan perilaku selektif dalam memilih bahan makanan (daging yang tidak berformalin, mie yang tidak berformalin, dan bakso yang tidak mengandung boraks), serta membudayakan perilaku menyimpan makanan di tempat tertutup atau menggunakan tudung saji. Hal ini

menunjukkan bahwa masyarakat Kelurahan Tirto telah memiliki pengetahuan yang memadai tentang

sanitasi makanan dan minuman. Pengetahuan yang memadai tentang sanitasi makanan dan minuman akan sangat mempengaruhi higiene pengolah

makanan, keamanan proses pengolahannya, serta kualitas makanan yang dihasilkan (Ningsih, 2014) .

\section{Pengamanan Sampah Rumah Tangga} Pengamanan sampah rumah tangga merupakan pilar 4 STBM. Permasalahan sampah rumah tangga memang menjadi budaya masyarakat Kelurahan Tirto. Mereka memilih lahan pekarangannya (lahan kosong) untuk dijadikan tempat pembuangan sampah kemudian dibakar. Selain itu, sampah juga dibuang ke sungai. Namun, seiring berjalannya waktu dan teknologi yang semakin moderen pemerintah Kelurahan Tirto mengambil 
kebijakan untuk memasang peringatan larangan membuang sampah secara sembarangan. Hal tersebut tidak sematamata hanya sebuah kebijakan dan komitmen saja di Kelurahan Tirto. Pihak Kelurahan Tirto menyediakan sebuah tempat untuk mengelola sampah secara aman yang disebut dengan TPS 3R

(melakukan pengurangan/ reduce, penggunaan kembali/reuse, dan pengolahan kembali/ recycle). Komitmen yang cukup kuat untuk mencapai hasil maksimal pada pilar 4 STBM ini menggugah para pembuat kebijakan di Kelurahan tersebut untuk segera mengoperasikan TPS 3R dan armada tossa sebagai pengangkut sampah rumah tangga. Teknis yang dipilih mereka adalah mengumpulkan sampah rumah tangga disuatu tempat (lahan kosong) kemudian seminggu 2-3 kali diangkut oleh armada tersebut untuk dibawa ke TPS 3R (tempat mengolah sampah, memilah sampah, dan mendaur ulang sampah). Penyelenggaraan ini akan digerakan oleh KSM di wilayah Tirto bersama LPM. Kondisi serupa juga terjadi di Kampung Rajawali dan dilaporkan dalam penelitian Puspawarti dan Besral (2008). Kesadaran

dan komitmen masyarakat dalam penanganan sampah harus diimbangi dengan penyediaan fasilitas sanitasi yang memadai (Nyakaana, 2010; Nkwachukwu, et al., 2010).

\section{Pengamanan Limbah Cair Rumah Tangga}

Pengamanan limbah cair rumah tangga merupakan pilar 5 STBM. Terdapat beberapa hal yang menghambat capaian pilar tersebut. Pertama, sebagian kecil masyarakat saja yang memiliki bak penampung limbah cair rumah tangga sebagai filter limbah secara tradisional sebelum dialirkan ke sungai. Masyarakat lainnya tidak memiliki bak penampung.
Artinya, penyediaan sarana prasarana bak penampung milik pribadi sangat minim. Para pemilik bak penampung limbah cair rumah tangga pun minim pengetahuan tentang tata letak antara saluran pembuangan/bak limbah cair dengan sumur resapan harus berjauhan. Sebab jika hal tersebut tidak dilakukan dapat menjadi tempat perindukan virus penyebab penyakit bahkan air sumur dapat tercemar.

Secara teritorial, sungai di Kelurahan Tirto berada di antara Kota Pekalongan dengan Kabupaten Pekalongan. Sungai tersebut menjadi muara pembuangan limbah cair rumah tangga. Muara limbah tersebut berasal dari

Kabupaten Pekalongan. Tetapi, mengalirnya menuju Kota Pekalongan. Sehingga penyelesaian masalah limbah cair rumah tangga harus ada koordinasi antara Pemerintah Kabupaten Pekalongan dengan Kota Pekalongan.

Strategi pemberdayaan masyarakat dengan mengumpulkan dana yang berasal dari swadaya masyarakat Kelurahan Tirto untuk mewujudkan penambahan bak penampungan besar limbah cair rumah tangga. Pada intinya, strategi-strategi diatas dapat terealisasi dengan baik manakala kesadaran masyarakat terbuka (open minded). Dengan kata lain, kesadaran masyarakat yang masih minim akan pengelolaan limbah cair rumah tangga secara aman menjadi titik masalah dari capaian pilar 5 STBM saat ini. Masyarakat Kelurahan Tirto belum memahami betul akan dampak jika mengalirkan limbah tersebut secara sembarangan (dapat mencemari sungai dan menimbulkan penyakit) dan kesadaran untuk memelihara Saluran Pembuangan Air Limbah (SPAL) juga masih minim. Kesadaran dan komitmen masyarakat dalam penanganan air limbah harus dibangun atas dasar 
pemahaman yang benar tentang pentingnya pengelolaan air limbah (Ling, 2012).

\section{Strategi Baru}

Berdasarkan uraian pada masingmasing pilar STBM di atas, maka diperlukan strategi-strategi baru untuk membenahi implementasi pilar-pilar STBM di Kelurahan Tirto. Sebagaimana dikutip dalam Nawawi (2012), manajemen strategik diwujudkan dalam bentuk perencanaan berskala besar dalam arti mencakup seluruh komponen di lingkungan sebuah organisasi yang dituangkan dalam bentuk rencana strategik (renstra) yang dijabarkan menjadi bentuk perencanaan operasional (renop), yang kemudian dijabarkan pula dalam bentuk program kerja atau proyek tahunan. Adapun strategi tersebut dapat dijelaskan sebagai berikut:

a. Upaya menerapkan punishment dari Kelurahan Tirto untuk mencapai Kelurahan $O D F$ bagi pelaku yang mengalirkan pembuangan feses ke sungai.

b. Upaya menjalin koordinasi antara Pemerintah Kota Pekalongan dengan Pemerintah Kabupaten Pekalongan untuk bersama-sama mengelola limbah cair rumah tangga secara aman..

c. Upaya pelatihan teknis STBM bagi tokoh masyarakat untuk mencapai perilaku buang air besar secara sehat di Kelurahan Tirto.

d. Upaya penambahan bak penampungan limbah cair rumah tangga melalui swadaya masyarakat atau iuran masyarakat.

\section{SIMPULAN}

Berdasarkan hasil penelitian yang dilakukan di Kelurahan Tirto Kecamatan Pekalongan Barat Kota Pekalongan tentang strategi promosi kesehatan STBM, maka dapat ditarik kesimpulan sebagai berikut:

1. Strategi advokasi lima pilar STBM yang diupayakan oleh Kelurahan Tirto belum menuai capaian secara maksimal pada pilar stop BABS dan pilar pengelolaan limbah cair rumah tangga secara aman. Konsistensi komitmen yang tegas belum diterapkan bagi pelaku yang mengalirkan pembuangan feses ke sungai. Selain itu, penyediaan sarana bak penampungan di Kelurahan Tirto tidak mencukupi total limbah cair rumah tangga yang dihasilkan.

2. Strategi bina suasana lima pilar STBM yang diupayakan oleh Kelurahan Tirto belum menuai capaian secara maksimal pada pilar stop BABS atau $O D F$. Belum adanya pelatihan teknis STBM bagi tokoh masyarakat menjadi faktor penghambat saat penyuluhan CLTS (pemicuan). Metode CLTS bersifat terbatas di satu RW. Sehingga, CLTS yang dilakukan tidak dapat menjangkau di 8 RW Kelurahan Tirto.

3. Strategi pemberdayaan masyarakat lima pilar STBM yang diupayakan oleh Kelurahan Tirto belum menuai capaian secara maksimal pada pilar stop BABS dan pengelolaan limbah cair rumah tangga secara aman. Pemberdayaan masyarakat melalui pemicuan saja tidak cukup. Masyarakat Kelurahan Tirto belum mengoptimalkan swadaya atau iuran secara kolektif untuk menyediakan penambahan sarana sanitasi berupa septic tank dan bak penampungan.

4. Pengkajian strategi promosi kesehatan pada lima pilar STBM di Kelurahan Tirto melalui analisis SWOT menghasilkan strategi baru untuk menghadapi akses universal sanitasi maupun mendukung program 100-0- 
100 pada tahun 2019 mendatang antara lain (1) upaya menerapkan punishment dari Kelurahan Tirto untuk mencapai Kelurahan $O D F$ bagi pelaku yang mengalirkan pembuangan feses ke sungai, (2) upaya menjalin koordinasi antara Pemerintah Kota Pekalongan dan Pemerintah Kabupaten Pekalongan untuk bersama-sama mengelola limbah cair rumah tangga secara aman, (3) upaya pelatihan teknis STBM bagi tokoh masyarakat untuk mencapai perilaku buang air besar secara sehat di Kelurahan Tirto, dan (4) upaya penambahan bak penampungan limbah cair rumah tangga melalui swadaya masyarakat atau iuran masyarakat.

\section{UCAPAN TERIMA KASIH}

Ucapan Terimakasih disampaikan kepada Kepala Kelurahan Tirto Kecamatan Pekalongan Barat Kota Pekalongan beserta jajarannya dan Kepala Puskesmas Tirto beserta jajarannya.

\section{DAFTAR PUSTAKA}

Anderson. 1979. Public Policy Making. New York: Holt Rinehart and Winston

Direktur Perumahan dan Pemukiman Bappenas. 2015. Arah Kebijakan Program PPSP 20152019. Jakarta: Bappenas

Kemenkes RI. 2014. Data dan Informasi Tahun 2014 (Profil Kesehatan). Jakarta: Kemenkes RI

Ling, T.Y., Dana, M.J., Bostam, S., and Nyanti, L. 2012. Domestic Wastewater Quality and Pollutant Loadings from Urban Housing Areas. Iranica Journal of Energy \& Environment. 3 (2): 129-133

Nawawi, Hadari. 2012. Manajemen Strategik Organisasi Non Profit Bidang Pemerintahan. Yogyakarta: Gadjah Mada University Press
Ningsih, Riyan. 2014. Penyuluhan Hygiene Sanitasi Makanan dan Minuman, Serta Kualitas Makanan yang Dijajakan Pedagang di Lingkungan SDN Kota Samarinda. Jurnal Kesehatan Masyarakat (KEMAS). 10 (1): 6472

Nkwachukwu, Onwughara Innocent., Chidi, Nnorom Innocent., and Charles, Kanno Okechukwu. 2010. Issues of Roadside Disposal Habit of Municipal Solid Waste, Environmental Impacts and Implementation of Sound Management Practices in Developing Country "Nigeria". International Journal of Environmental Science and Development. 1 (5): 409-418

Nyakaana, Jockey B. 2010. Solid waste management in urban centers: The case of Kampala CityUganda. East African Geographical Review. 19 (1): $33-43$

Peltzer, Karl and Pengpid, Supa. 2014. Oral and hand hygiene behaviour and risk factors among inschool adolescents in four Southeast Asian countries. International Journal of Environmental Research and Public Health. 11 (3): $2780-2792$

Peraturan Menteri Kesehatan RI Nomor 3 Tahun 2014 Tentang Sanitasi Total Berbasis Masyarakat.

Profil Kelurahan Daftar Isian Potensi dan Perkembangan Tahun 2014, Kelurahan Tirto, Kecamatan Pekalongan Barat, Kota Pekalongan.

Puspawati, Catur dan Besral. 2008. Pengelolaan sampah berbasis masyarakat di Kampung Rajawali Jakarta Selatan. Jurnal Kesehatan Masyarakat Nasional (Kesmas). 3 (1):9-15

Rekapitulasi Data Kelurahan STBM dan Kelurahan ODF Dinas Kota Pekalongan Tahun 2014.

Sidjabat, Erickson. 2012. Partisipasi Masyarakat Desa dalam Implementasi Strategi Nasional Sanitasi Total Berbasis Masyarakat di Kabupaten Grobogan. Tesis. Jakarta: Universitas Indonesia.

Susila, Siswanto dan Suyanto. 2013. Metodologi Penelitian Kesehatan dan Kedokteran. Yogyakarta: Bursa Ilmu 
Trikora, Endang dan Siwiendrayanti, Arum. 2015. Hubungan Praktik Cuci Tangan, Kriteria Pemilihan Warung Makan Langganan dan Sanitasi Warung dengan Kejadian Diare pada Mahasiswa Universitas Negeri Semarang. Unnes Journal of Public Health. 4 (1): 48

Wandansari, Arry Pamusthi. 2014. Hubungan antara Kualitas Sumber Air Minum dan Pemanfaatan Jamban Keluarga dengan Kejadian Diare di Desa Karangmangu Kecamatan Sarang Kabupaten Rembang. Unnes Journal of Public Health. 3 (3): 1-8
Windraswara, Rudatin. 2009. Keterlibatan Komunitas dalam Perencanaan Sanitasi pada Daerah Rawan Bencana. Jurnal Kesehatan Masyarakat (KEMAS). 5 (1): 58-63

Yimam, Yimam Tadesse., Gelaye, Kassahun Alemu., and Chercos, Daniel Haile. 2014. Latrine utilization and associated factors among people living in rural areas of Denbia district, Northwest Ethiopia, 2013, a cross-sectional study. The Pan African Medical Journal.18:334 